\title{
Analysis of the application of the Think Methodology according to the American Think Book
}

DOI: https://doi.org/10.33262/ap.v3i3.1.91

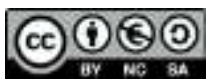

Análisis de la aplicación de la Metodología Think de acuerdo al Libro American Think

Ambar Verenice Morocho Torres. ${ }^{1}$, Edison Hernán Salazar Calderón. ${ }^{2}$, Luis Oswaldo Guadalupe Bravo. ${ }^{3} \&$ David Antonio Ureña Lara. ${ }^{4}$

\begin{abstract}
.
Introduction. By means of a previous analysis, it was determined students of the Second Year "B" of Bachillerato General Unificado at "Combatientes de Tapi" High School, are not cognitively committed with the development of their performance in English due to the inadequate development of the "THINK" methodology. Objective. This study analyzed how THINK methodology helps to reinforce thinking and language skills in students. Methodology. This analysis was developed in Second Year "B" of Bachillerato General Unificado at "Combatientes de Tapi" High School, during the first term of the 2017-2018 school year. The population was 35 students; twenty-five of them men and ten women. The type of study was ethnographic and qualitative at an exploratory level. A non-participatory observation technique was used since the researcher plays a passive role; the data collection instrument was an observation guide. Results. It was determined

1 CEI Thomas Edison, Idiomas, Riobamba, Ecuador. ambarmt9605@gmail.com, http://orcid.org/00000003-4095-0337

2 Escuela Superior Politécnica de Chimborazo, Facultad de Ciencias. Riobamba, Ecuador. edisonh.salazar@espoch.edu.ec, https://orcid.org/0000-0002-7911-9623

3 Escuela Superior Politécnica de Chimborazo, Facultad de Ciencias. Riobamba, Ecuador. loguadalupe@espoch.edu.ec, https://orcid.org/0000-0002-1482-0312-7631-2102

4 Escuela Superior Politécnica de Chimborazo, Facultad de Recursos Naturales. Riobamba, Ecuador. david.urenia@espoch.edu.ec, https://orcid.org/0000-0002-1482-0312
\end{abstract}


that, in the current educational year, THINK methodology helps students to develop the ability to think critically together with improvements in language skills and should be applied according to the established order, paying great attention to promoting thinking skills and promoting language skills. Conclusions. It is concluded that the teacher rarely applied the methodology with high proficiency and just some of the recommended strategies to develop critical thinking were used.

Keywords: Think Methodology, Critical Thinking, English Learning

\section{Resumen.}

Introducción. A través de un análisis previo se determinó que los estudiantes del Segundo Año de Bachillerato General Unificado "B" en la Unidad Educativa "Combatientes de Tapi", no están cognitivamente comprometidos en el desarrollo de su desempeño en inglés, debido al inadecuado desarrollo de la metodología "THINK". Objetivo. Este estudio analizó como la metodología THINK ayuda a reforzar las destrezas de pensamiento y lenguaje en los estudiantes. Metodología. Este análisis fue desarrollado en el Segundo Año de Bachillerato General Unificado "B" en la Unidad Educativa Combatientes de Tapi" durante la primera parte del año lectivo 2017-2018. La población fue de 35 estudiantes; veinticinco de ellos varones y diez mujeres. El tipo de estudio fue cualitativo de nivel exploratorio y el método cualitativo empleado fue de tipo etnográfico. Se utilizó una técnica de observación no participativa ya que el investigador protagoniza un rol pasivo; el instrumento de recolección de datos fue una guía de observación. Resultados. Se determinó que en el presente año educativo, la metodología THINK ayuda a los estudiantes a desarrollar la capacidad de pensar críticamente conjuntamente con mejoras de las destrezas del lenguaje y que debe ser aplicada conforme al orden establecido, prestando gran atención a fomentar las destrezas de pensamiento y promoviendo mejoras en las técnicas del desarrollo de las destrezas de lenguaje. Conclusiones. Se concluye que el profesor raramente se aplica la metodología con alto dominio y solamente se aplican algunas de las estrategias para desarrollar el pensamiento crítico y con un orden distinto al recomendado.

Palabras claves: Think Methodology, Pensamiento Crítico, Aprendizaje de Inglés.

\section{Introduction.}

A human's capacity of solving problems is one of the important aspects in our life; not possessing qualified thinking can lead any one to trouble themselves as well as the society. An interesting statement was made by Paul (2003) about the quality of thinking: "Everything we do in life is determined by the quality of our thinking. If we aren't thinking clearly, we're at the mercy of everyone else". Taking this in mind is important more than ever, for teachers to teach to their students to think even when they are learning a new language. 
This analysis was performed in "Combatientes de Tapi" High School, which is located in Juan de Velasco parish, city of Riobamba, in Chimborazo province, this institution offers education in the Initial, Basic and High school education. It was founded as a military school, but since May 6th 2016, the institution turned their administration model into a fiscal system.

Even when the Ecuadorian Education Ministry has it owns English books for all the educational levels, it includes Bachillerato General Unificado (BGU). The institution used to keep on working with Cambridge University Press collaboration and their books American THINK for BGU levels, which have been developed according to Herbert Puchta methodology "Developing young learners' thinking skills", which is the basis for this research.

The study problem was found in the 2nd year "B" of BGU at "Combatientes de Tapi", where there are 35 students, 25 of them are boys and 10 are girls, between the ages of sixteen and seventeen years old. The purpose of this research, was to analyze how THINK methodology can help to enhance language and thinking skills in the students at the 2nd year class "B" of BGU 2 at "Combatientes de Tapi, in the city of Riobamba, during the first school period $2017-2018$.

This analysis explored and got information about how THINK methodology works on developing learners thinking beyond enhancing not only language, this methodology is based in four principal aspects which supports the whole teaching method, through the info recovered was possible to determine that there was an inadequate application of "THINK" methodology, also the strategies used by the teacher to enhance thinking and language skills do not permit to the students to bring out the very best from them. This research will establish which would be the best process to follow for enhancing language and thinking skills. Once established that process, the present research will strengthen THINK methodology development.

\section{Methodology.}

This was a qualitative research because it would be characterized by the use of data that arose from the empirical confrontation between the subject and the object of investigation with emphasis on interpretation results. At a level of knowledge had an exploratory scope because it would help us to analyze how THINK methodology was being applied by the teacher with her students of 2 nd year class "B" of Bachillerato General Unificado at "Combatientes de Tapi" in order to enhance language and thinking skills.

As it is descibed in Metodologia de la Investigación 5ta Edición, the exploratory scope "looks up for little studied problems, help to identify promising concepts and prepare the field for new researches”. (Hernández Sampieri, Fernández Collado, \& Baptista Lucio, 2010)

This research was carried out based on the ethnographic method because this is suited for the educational field; this anthropological technique gathers information about human 
behavior which will help to the researcher to describe the developing of THINK methodology.

This study lasted six months and it had been distributed by the following faces: the field work place, the analytical phase and informative phase.

Due to the small population was not necessary to take a relatively sample. Population was represented by the English teacher and 35 students of 2 nd year class " $\mathrm{B}$ " of 25 Bachillerato General Unificado at "Combatientes de Tapi" analyze during the first Term School period $2017-2018$.

The researcher has already worked with this population when was developing the PreProfessional Execution practices at this institution. Then, it was evident the lack of student's compromise with their English performance improvement, when they were working out the activities and during the English lessons with the teacher.

This research activity has been divided into; preparatory, work field, analytical and informative. Firstly, the principal field of this research is "English Methodology", because as was already mentioned before the methodology's importance for an EFL teacher is highly related with how the teaching - learning process is being developed. For this reason, the researcher selected this population in specific in order to explore how THINK methodology could help to enhance language and thinking skills in the students at the 2nd year class "B" of Bachillerato General Unificado at "Combatientes de Tapi".

The problem was chosen while the teaching practices were developed due to the deeply interest that the researcher had on; why students got so easily distracted and bored when they were working out the activities during the English classes along the week, how they were relying the subject as a matter of less important without taking in mind how important is this subject for the globalized world. And also what the teacher did for prevent that or in the other hand promote that.

For carrying out the investigation, it was primary necessary to ask for the institution principal authority consent, the assertive response to the researcher petition. Thanks to the direct contact that the researcher already had had with the direct participants of the project during the teaching execution practices developed before. When the researcher 26 exposed her interest analyze for improving and contribute with the educational improvement of this institution, the principle authorities showed their willing to contribute with that purpose. Through the non-participant observation, the researcher limited herself to be a passive observer and data collector, without participating in the teacher's activities along the English classes. Meanwhile the teacher and students were developing their activities as their normal routine, it was useful for the researcher because due to the ethnographic research method it is necessary to observe the human behavior or in this case the English class as it is, without the pressure of being observed.

For data collection was necessary two applied an instrument an observation sheet or well know like a tally sheet. This tool was designed to gather evidence about how the teacher 
was using THINK methodology in English classes, by means of indicators, that described the aspects of THINK methodology principles and if they are being accomplished during the teaching-learning process, also it helped to observe which activities the teacher used for enhancing the fourth language skills in order to empower the students English development.

After gather the information was possible to analyze that teacher was not full accomplishing THINK principles which foster student's development as a hole learners which should had been able to be deeply engaged in the environment and issues that surround them. The students were distracted; they complete the activities just to fulfill the answers, copy from others without a real process of critical thinking proper of the BGU students, they were not trying to improve their English performance. The data collection ended because it was possible to accomplish the specific objectives of this research.

Results.

Table 1

Results of the survey applied to the teacher

\begin{tabular}{ll}
\hline \multicolumn{1}{c}{ Analysis } & Theory Contrast \\
\hline SPECIFIC OBJECTIVE
\end{tabular}

SPECIFIC OBJECTIVE

To observe how the teacher is using THINK methodology in the English classes.

COLLECTED INFORMATION

Teacher does not foster a deeper level of engagement in her students.

Even with provided information it was possible THiNK methodology works with high interesting to observe that: topics and a special focus on developing 1. Teacher doesn't foster a deeper level of cognitive skills challenge and inspire teens to engagement as it would be expected with this become lifelong learners, to achieve these methodology, because even when the English certain principles should be accomplishing: teacher works with "American Think Book" teacher's guide, and this provides the answers and also techniques of how to work out and develop certain activities along the English THiNK explores complex issues and topics of classes, teacher did not try to reach the very interest to teens and offers insights into other best of her students, where students with people and cultures. higher abilities than the others were just Taking in mind what the author of THiNK limited to get a good grade and sometimes methodology has explained in "Developing help the teacher. What would be expected to young learners thinking skills series" (Puchta, be done was apply the scaffolding principle, 2015) who argued that his approach has two which is one of the bases of THiNK mainly advantages in order to achieve this goal. methodology. The students were not truly First, activities that are meaningful and at the intellectual challenged by the teacher when same time intellectually challenging are more they were not capable of solving problems by likely to achieve a higher level of cognitive their own or even been concerned about the engagement from learners than those ELT global world problems that were presented in activities that can be somewhat over-simple the textbook through context in the from a cognitive point of view. Secondly, the content.Students did reach the very best that tasks that have been developed have a realthey should have given. world purpose; examples include problem solving, decision making, thinking about the consequences of one's own or other people's actions, and so on". 
Tabla 1

Results of the survey applied to the teacher (Next part)

\section{COLLECTED INFORMATION}

Teacher does not build good habits of mind in her students

2. In relation to Building good habits of mind: Build good habits of mind

Students most of the time were able to just answer questions where the answer were already explicit in the text book, without realizing a real process of developing a critical sequence of problem solving process according to their critical thinking skills. Even when teacher asked open question most of the students weren't able to answer these kind of question without problem. And just a few

THINK activities are integrated into lessons that help the students to sharpen their critical thinking skills-from sequencing and problem solving to evaluating information and supporting opinions-developing the habits of mind that are essential to successful learning across the curriculum.

students felt free to ask for clarification of the (Puchta Herbert et al., 2017) question or ask for help to answer it, or answer it by their own.

\section{COLLECTED INFORMATION}

The teacher instills positive values in her students

3. As was mentioned before, student's age's fluctuate between sixteen and seventeen years' old. And at the moment of Instill positive values it was difficult to keep an environment where students were supposed to be difficult to manage with, or also to show respect between them. Even when this was expected to deal with, it was possible to observe how the teacher was instilling to their students to be respectful between others and how important was to have a positive social behavior for their future, when they are expected to be mature teenagers who behave according to the social standards. The teacher has a really good relation with most of the students, they are able to talk freely about their personal issues in their mother tongue.

\section{COLLECTED INFORMATION}

The teacher promotes a healthy self-esteem in her students.

4. The teacher has a good relation with her Promote healthy self-esteem

students, she spends a good amount of time of A healthy self-esteem is close related with the English classes, when was necessary, in order student's engagement mentioned before, the to make students become conscious about sense of positive school, peer, and family their future and how the way how students' self- connectedness (feeling that one "fits in" and esteem play a very important place in their "belongs") protects youth from engaging in lifetime and what they want to achieve a long negative health behavior.

their lives. It was also possible to observe that Agreeing with King, (2010) that a positive teacher pay specially attention to certain social connections decrease risk-taking students at the moment to make error behavior by providing youth with prosocial and corrections without make them feel empowering opportunities. Youth who feel uncomfortable or angry about that.
Instill positive values

students to reflect on positive social behaviors and important universal values such as understanding of global issues and appreciation and respect for others.

as (Sigsworth L., 2017) explains in her classroom" she explains: "Teachers are already under pressure to teach an increasing number of subjects in an already crowded not always lucky enough to have a stable and safe home life, it is undoubtedly the responsibility of educators to pick up the slack, explore ideas of responsibility, empathy and cultural difference". supported and cared for by parents, teachers, and peers report feeling more efficacious in making healthy, informed decisions and displaying features of resiliency to potential life stressors. 
Tabla 1

Results of the survey applied to the teacher (Next part)

\section{SPECIFIC OBJECTIVE}

To recognize which activities are being used by the teacher to empower language and thinking skills in the students.

\section{COLLECTED INFORMATION}

At the moment of practice language skills and empower thinking skills in the students of 2 nd year class "B" of Bachillerato General Unificado at "Combatientes de Tapi", the English teacher worked in a traditional way the language skills. It means that just a few, basic questions were done at the moment of speaking, students were not able to ask for information in English, or maintain a short dialogue as it was expected to be.

Students are not familiarized to write long texts, or write in blogs as it is one of the suggestions of THiNK methodology.

Even when the communication between teacher and students were not a problem. It is important to say that it's difficult to promote the four language skills practice in a 35 student's classroom without calling for attention once and again and catch students whole attention and their best effort in learning English. The language skills practice was set aside while the English class were developed. Some students were paying attention and making questions for just full filling book activities, but most of the students were talking between them, and some were distracted by doing other subjects assignments. It was not evident that teacher fully encouraged to her students to develop a critical thinking where produce problem solving strategies by themselves is one of the basis of this, students

were not completely focused in pay more attention than required in the tasks that are being developed with topics which appeals student's attention, creativity, sense of responsibility and more.

\section{SPECIFIC OBJECTIVE}

To stablish which would be the best process to follow for enhancing language and thinking skills

\section{COLLECTED INFORMATION}

After analyzing facts and theory about how the teaching-learning process should be developed in order to reach the principles of THiNK methodology and the New Curriculum presented by the Ecuadorian National Ministry and its guidelines for the Subnivel BGU, it is important to bear in mind that some steps are missing, there some strategies that are not being applied as they should be. To bring out all of the student's potential, the author of THiNK methodology has shown special attention in combining certain high-order thinking skills in order to empower critical thinking and language skills at the same time. 
Tabla 1

Results of the survey applied to the teacher (Next part)

Its known that the teacher is the one of the Activity types to develop thinking skills and main elements into the teaching -learning language

process, even when this methodology has According to Herbert Puchta (2015) in his article been developed in order that students are "Developing young learners' thinking skills \#5capable to construct their own knowledge and Combining the teaching of thinking and it a student centered teaching, it is important language", he had established 13 categories of that the teacher that is going to be leading this activity that help with both the development of process is totally conscious about how to do it. the learners' thinking skills and their language. Taking in mind how high-order thinking These established steps follow a basic to a activities had been classified into steps by high-order thinking skills guide:

Herbert Puchta in

his article 'Developing young learners' $\square$ Categorizing

thinking skills \#5 - Combining the teaching of $\square$ Sequencing

thinking and language".

It is truly important for a teacher keep of learning through new methods and techniques to go with the constant changing world.

THiNK methodology has been developed through constructs based of teacher and student's needs. Teacher should pay specially attention to the various techniques provided by the co-author of the text book, about how to apply this methodology, all this information can be found in the own teachers-book, on line resources of the Flexible digital support that includes Presentation Plus classroom presentation software, online workbooks and interactive e-books. Using the Graded Workbook activities and the extra ideas in the Teacher's Book that are perfect for mixedability classes, those classes look for the whole student's development without put aside each student necessity.

Note. Source: This table was adapted from the original one which is part of a professional thesis. Morocho, A. (2018). Analysis of the application of think methodology, according to the "American Think Book", in the 2nd year class "B"of Bachillerato General Unificado at "Combatientes de Tapi" high school in the city of Riobamba, during the first quimester school period 2017 -2018. Retrieved from: http://dspace.unach.edu.ec/handle/51000/4772

\section{Conclusions.}

- The teacher is rarely developing THINK methodology with high proficiency.

- The teacher applies strategies to enhance thinking skills with low frequency, the most used are; questioning, mind movies, and elaborate their own answers. While when she enhances language skills she always uses note-taking and just sometimes uses extra material from internet which most of the time has the answers already given, make substitutions, and elaborate their own knowledge. There are so many strategies that more attention in both cases, for enhancing thinking and language skills.

- It has been analyzed that there are some strategies that have to be developed in certain order at the moment of enhancing thinking and language skills. 


\section{Bibliographic References.}

Cox, J. (2017). Teaching Strategies that Enhance Higher-Order Thinking [TeachHUB.com]. Retrieved October 5, 2017, from http://www.teachhub.com/teaching-strategies-enhance-higher-order-thinking

Hernández, S., Fernández C., C., \& Baptista, P. (2010). Metodología de la investigación (5a ed). México, D.F: McGraw-Hill.

King, K. A., Vidourek, R. A., Davis, B., \& McClellan, W. (2002). Increasing self-esteem and school connectedness through a multidimensional mentoring program. Journal of School Health, 72(7), 294-299.

Ministerio de Educación del Ecuador. (2010). English as a Foreing Language -forSubnivel-Bachillerato General Unificado (Vol. I). Ecuador. Retrieved from https://educacion.gob.ec/wp-content/uploads/downloads/2016/08/EFL-forSubnivel-BGU-final-ok.pdf

Morocho, A. (2018). Analysis of the application of think methodology, according to the "American Think Book", in the 2nd year class "B"of Bachillerato General Unificado at "Combatientes de Tapi" high school in the city of Riobamba, during the first quimester school period 2017 -2018. [Tesis para la obtención del título profesional, Universidad Nacional de Chimborazo]. Repositorio Académico de la Universidad de Chimborazo. http://dspace.unach.edu.ec/handle/51000/4772

Paul, R., \& Elder, L. (2001). Critical Thinking: Tools for Taking Charge of Your Professional and Personal Life. (1st Edition). U.S. Prentice Hall.

Puchta, H. (2015, April 16). Developing young learners' thinking skills \#5 - Combining the teaching of thinking and language. Retrieved January 22, 2018, from http://www.cambridge.org//elt/blog/2015/04/16/combining-teaching-thinkinglanguage-teaching/

Puchta, H., Stranks., Jeff \& Lewis-Jones, P. (2017). Think| Secondary. Retrieved July 3, 2017 , from http://www.cambridge.org/us/cambridgeenglish/catalog/secondary/think/

Sigsworth L. (2017). THiNK Thursday \#4: Incorporating values into the teen classroom. Retrieved July 8, 2017, from http://www.cambridge.org//elt/blog/2017/05/04/think-thursday-4-incorporatingvalues/

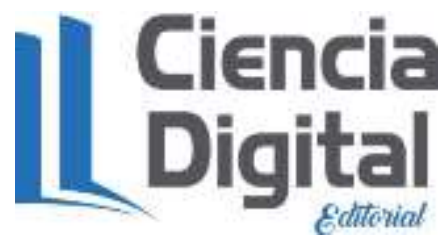




\section{PARA CITAR EL ARTÍCULO INDEXADO.}

Morocho Torres, A. V., Salazar Calderón, E. H., Guadalupe Bravo, L. O., \& Ureña Lara, D. A. (2021). Analysis of the application of the Think Methodology according to the American Think Book . AlfaPublicaciones, 3(3.1), 261-270. https://doi.org/10.33262/ap.v3i3.1.91

\section{LCiencia}

El artículo que se publica es de exclusiva responsabilidad de los autores y no necesariamente reflejan el pensamiento de la Revista Alfa Publicaciones.

El artículo queda en propiedad de la revista y, por tanto, su publicación parcial y/o total en otro medio tiene que ser autorizado por el director de la Revista Alfa Publicaciones.
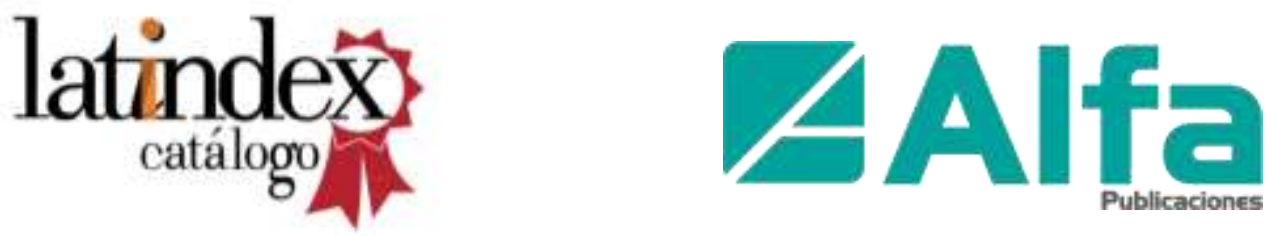